\title{
Extended Aspects of Growth Hormone (GH) Action: GH Receptor (GHR) mRNA Expression in Various Bovine Tissues and Effects of a Long-Term Treatment with GH on GHR mRNA and on GH Binding in Liver
}

\author{
Rainer RÖPKE, Helga SAUERWEIN, Boris STOFFEL, \\ Kerstin HAGEN-MANN, Sabina von AHNEN and Heinrich H.D. MEYER \\ Institut für Physiologie, Forschungszentrum für Milch \\ und Lebensmittel Weihenstephan, Technische Universität München, \\ 85350 Freising, Germany
}

\begin{abstract}
The expression of the bovine growth hormone receptor (GHR) was detected in various tissues by a reverse transcription - polymerase chain reaction system (RT-PCR). For the quantification of the bovine 438 bp GHR cDNA fragments a HPLC-UV detection system was used. bGHR amplificates were well detectable in liver from cows, heifers and in fetal liver. bGHR expression was also demonstrated in mammary gland, kidney and in adipose tissue. Lower but significant amounts of bGHR amplificates were obtained in skeletal muscle and in rumen villi, indicating a potential new mode of action of GH via affecting the gastrointestinal tract. bGHR mRNA was detected in various female and male reproductive tissues, i.e. in uterus, oviduct, corpus luteum, and in the vesicular gland. No bGHR expression was detectable in testes from adult bulls. A longterm treatment of heifers with a slow-release preparation of bovine growth hormone had no effect on either bGHR-mRNA expression in liver or on GH binding capacity on liver membrane preparations. These results demonstrate that the RT-PCR system together with a HPLC-UV detection system provides a useful strategy to study GHR expression and regulation in different tissues under various conditions.
\end{abstract}

Key words: GH receptor, Bovine, RT-PCR.

(J. Reprod. Dev. 40: 227-234, 1994)

G rowth hormone $(\mathrm{GH})$ plays a keyrole in regulating glucose, fat and protein metabolism [1, 2]. Besides its direct effects on adipose tissue, where it acts lipolytically, it is now generally accepted that GH either directly or indirectly stimulates anabolic processes such as cell division, skeletal growth and protein synthesis. The anabolic effects are believed to be indirect, i.e. mediated by insulin-like growth factor-1 (IGF-1). The major

Accepted for Publication: May 27, 1994

Correspondence: H. Sauerwein source for circulating IGF-1 is the liver [3], where it is synthesized and secreted in response to $\mathrm{GH}$ stimulation. Furthermore, many tissues have the capacity to synthesize IGF-1 [3], which has led to the concept that IGF-1 can act locally close to its site of synthesis as paracrine or autocrine factor. Increasing evidence suggests that $\mathrm{GH}$ has direct effects in tissues other than fat and liver, although the demonstration of a direct $\mathrm{GH}$ action in vitro does not exclude local IGF-1 production as a mediator of the observed effects. The presence of specific GH receptors (GHR) in the respective tissues is the prerequisite for $\mathrm{GH}$ action. To investi- 
gate the GH sensitivity of various tissues, the determination of GHR can be approached on the transcriptional (measurement of the specific GHR mRNA) as well as on the translatory level (recordings of the mature protein, e.g. by binding studies). Gene expression studies have a number of advantages compared to conventional protein assays, e.g. the sensitivity in detecting gene products even at a low transcription level. To investigate GHR expression in various bovine tissues that are of particular interest with respect to metabolism and to reproduction, we aimed to use the Reverse Transcription- Polymerase Chain Reaction (RTPCR). The bovine GHR cDNA sequence contains a coding region for 634 amino acids and at the 3' end (free hydroxyl group) a non-translated area with poly-A-tail of 1927 nucleotides; the coding sequence consists of a signal sequence with 18 amino acids, an extracellular domain with 242 amino acids, a transmembranous domain with 24 amino acids and an intracellular domain with 350 amino acids [4]. Based on this sequence, we developed a RT-PCR system for bovine GHR mRNA detection. In order to allow a comparison of the amount of RT-PCR amplificates obtained, we developed and validated a quantitative approach using HPLC-UV. This technique was used to investigate the effect of a long-term treatment with a slow release preparation of bovine $\mathrm{GH}$ on liver GHR in cattle. It was of particular interest whether this way of chronic GH application is affecting GHR in a similar way as reported previously for daily GH applications [5]. To substantiate our findings for GHR mRNA with respect to the mature protein, we assessed in parallel the GH binding capacity on hepatic membranes prepared from the respective animals.

\section{Materials and Methods}

\section{Animals and tissue collection}

Samples from skeletal muscle (m. splenius), white adipose tissue, rumen villi, kidney, liver, mammary gland, oviduct, luteal tissue, ovary tissue, uterus, testes and from the vesicular gland of German Simmental cattle (fetus, calf, heifer, cow, and bull) were collected at the local abattoir immediately after slaughter. They were snapfrozen in liquid nitrogen and were then stored at $-80 \mathrm{C}$ un- til analysis.

To investigate the effects of a long-term treatment with bovine somatotropin (bST=bovine GH) on hepatic GHR, 12 Simmental heifers were randomly allocated to three different groups that were treated with either 640,320 or $0 \mathrm{mg}$ (vehicle only) of recombinant bST formulated as a slow release depot preparation (rbST-Somidobove, Elanco, Eli Lilly). All heifers were fed with maize silage $a d$ libitum and $1.8 \mathrm{~kg}$ of concentrate/day; they were injected in 14 day intervals and the injections were placed into the ischiorectal fossa. This treatment was continued over a period of 38 weeks in average and covered the growth range between 290 and $520 \mathrm{~kg}$ live weight. Having reached this final live weight, the animals were slaughtered and liver samples were collected from the caudate lobe and were processed as described above. The efficacy of the treatment with regard to bGH and IGF-1 plasma concentrations as well as to growth rates and body composition is documented elsewhere [6].

\section{Isolation of $R N A$}

Extraction of total RNA was performed in presence of guanidinium salts according to Chirgwin et al. [7]. Total RNA from white adipose tissue was isolated as described by Tavanger et al. [8]. The concentration and the purity of total RNA were determined by measuring the $\mathrm{A}_{260 / 280}$ absorbance ratio which ranged from 1.5 to 2.0 , with yields between 150-250 $\mu \mathrm{g}$ total RNA/g tissue.

\section{Primer design}

Primers were selected from the bovine GHR cDNA sequence [4] to amplify the transmembrane region with flanking sequences in the intra- and extracellular parts. The primer sequences were determined with a computer program (OLIGO, MedProbe, Norway) and the primers required were custom synthesized (MWG-BIOTECH, Ebersberg, Germany).

Both bovine primers, the sense primer $(865-900$ bp; 5'-GAGTATGAACTGCGTGTGAGAACCAGACAACGAAAC-3') and antisense primer (12681303 bp; 5'-GTCATTGCTCAGAAGTCTGTCTGTGTCTGACCCTTC-3') spanned a bovine GHR cDNA sequence of $438 \mathrm{bp}$.

\section{Reverse transcription (RT) and polymerase chain reaction (PCR)}

Total RNA isolated from different bovine tis- 
sues was reverse-transcribed with MMULV-Reverse Transcriptase to produce a single-stranded bovine GHR cDNA fragment. The RT procedure was carried out as followed: $52 \mathrm{C}$ for $30 \mathrm{~min}$ and 99C for 1 min using $0.8 \mu \mathrm{g}$ total RNA as template in $20 \mu \mathrm{l}$ PCR buffer containing $10 \mathrm{U}$ RNase inhibitor (Gibco, Life Technologies, BRL, Eggenstein, Germany), 50 U Superscript Reverse Transcriptase (Gibco, BRL), $40 \mathrm{pmol}$ of antisense primer, $10 \mathrm{mM}$ Tris- $\mathrm{HCl} \mathrm{pH} 8.3,50 \mathrm{mM} \mathrm{KCl}, 5 \mathrm{mM} \mathrm{MgCl}_{2}$ plus 1 $\mathrm{mM}$ of each deoxynucleoside triphosphate. For PCR analysis RT products were subjected to 28 cycles of amplification with temperature steps of 94C for $1 \mathrm{~min}, 65 \mathrm{C}$ for $1 \mathrm{~min}$, and $72 \mathrm{C}$ for $1.5 \mathrm{~min}$. The PCR mixture consisted of $2.5 \mathrm{U}$ Taq polymerase (Perkin Elmer Cetus, Überlingen, FRG) in $100 \mu \mathrm{l} 1$ $\times$ PCR buffer containing $10 \mathrm{mM}$ Tris- $\mathrm{HCl} \mathrm{pH} 8.3$, $50 \mathrm{mM} \mathrm{KCl}, 2.0 \mathrm{mM} \mathrm{MgCl} 2,40$ pmol sense primer. The PCR products were electrophoresed on $1 \%$ agarose gels and visualized by ethidium bromide staining.

\section{Restriction enzyme analysis}

To verify the identity of the RT-PCR products, an analysis by restriction endonucleases was carried out. The amplified sequence had two sites for the restriction endonuclease HinfI (fragment sizes: $216 \mathrm{bp}, 130 \mathrm{bp}$ and $89 \mathrm{bp}$ ), one restriction site for EcoRI (fragment sizes: $104 \mathrm{bp}$ and $331 \mathrm{bp}$ ) and three sites for DdeI, where the site at position 424 could be ignored (fragment sizes: 83, 220 and 132 bp).

\section{High performance liquid chromatography (HPLC)}

For the comparative quantitative determination of RT-PCR amplificates, the high performance liquid chromatography (HPLC) technique by Katz \& Dong [9] followed by UV detection was used. Separation was achieved with a DEAE (diethylaminoethyl) anion exchange column (P-E TSK DEAE-NPP, Perkin Elmer Cetus, Norwalk, CT, USA). The column had a particle size of 2.5 $\mu \mathrm{m}$ and an ion exchange capacity of $0.15 \mathrm{meq} / \mathrm{ml}$. For the elution two different buffers, buffer A (1 M $\mathrm{NaCl}, 25 \mathrm{mM}$ Tris $\mathrm{pH} 9.0)$ and buffer B $(25 \mathrm{mM}$ Tris-HCL pH 9.0), were used in a gradient system at room temperature as follows: $25 \%-40 \% \mathrm{~A}$ in 0.5 $\mathrm{min}, 45 \%-50 \% \mathrm{~A}$ in $4.5 \mathrm{~min}, 50 \%-62 \% \mathrm{~A}$ in $15 \mathrm{~min}$, $62 \%-100 \%$ A in $3 \mathrm{~min}, 100 \%-25 \% \mathrm{~A}$ in $1 \mathrm{~min}$ with a pressure of $150 \times 10^{5} \mathrm{~Pa}$ and a flow rate of $1 \mathrm{ml} /$ min. UV detection was through a $6 \mu \mathrm{l}$ quartz cu- vette at a wavelength of $260 \mathrm{~nm}$ with a detection limit of about $0.2 \mathrm{ng}$ DNA. The extinction (E) at full deflection was $16 \mathrm{mE}$. The application loop had a total volume of $20 \mu \mathrm{l}$. A pBR322 Hae II digest (Sigma Chemie $\mathrm{GmbH}$, Deisenhofen, Germany) was applied in this HPLC-System to evaluate the separation and the relationship between the amount and the size of the fragments applied and the resulting peak integral.

\section{$G H$ radio receptor assay on liver membrane preparations}

Crude microsomal membranes were prepared as described previously [5]. Briefly, liver tissue was thawed and homogenized in 2 volumes of 25 $\mathrm{mM}$ Tris, $10 \mathrm{mM} \mathrm{CaCl}$, pH 7.6 containing 1000 Kallikrein inhibitory units (KIU; Aprotinin, Fluka, Switzerland) with an Ultra-Turrax equipment (Janke \& Kunkel, Staufen, Germany). After a 1000 $\times \mathrm{g}$ centrifugation for $1 \mathrm{~h}$ at $4 \mathrm{C}$, the resulting supernatant was incubated with $\mathrm{MgCl}_{2}$ to a final concentration of $2 \mathrm{M}$ for $20 \mathrm{~min}$ at $4 \mathrm{C}$ to remove endogenous bound GH. This preparation was then pelleted ( $1 \mathrm{~h}$ centrifugation at $40000 \times \mathrm{g}, 4 \mathrm{C}$ ). The pellet was resuspended in $25 \mathrm{mM}$ Tris, $10 \mathrm{mM}$ $\mathrm{CaCl}_{2}$, $\mathrm{pH} 7.6$ for washing, recentrifuged as before, finally suspended in $25 \mathrm{mM}$ Tris, $10 \mathrm{mM} \mathrm{CaCl}$, pH 7.6 containing $1000 \mathrm{KIU}$, aliquoted and stored frozen at $-30 \mathrm{C}$ until assayed.

Bovine pituitary extracted growth hormone (USDA-bGH-B-1) was ${ }^{125}$ I-labelled with a modified Lactoperoxidase method [10] to specific activities of $35 \mu \mathrm{Ci} / \mu \mathrm{g}$ in average. The radioreceptor assay was performed in triplicates at room temperature for $24 \mathrm{~h}$ using $100 \mu \mathrm{l}$ membrane preparation as described in detail for ovine GHR determination in liver previously [5]. Equilibrium was achieved under these conditions and the somatotropic nature of the bGH binding observed was confirmed in displacement studies of ${ }^{125} \mathrm{I}-\mathrm{bGH}$ with different concentrations of unlabelled bGH (recombinant bGH, 170 B, Eli Lilly, Greenfield, USA; 0$1000 \mathrm{ng} /$ tube) and of bovine prolactin (bPRL, NIHP-B3, $0-10 \mu \mathrm{g} /$ tube). The incubation was terminated by addition of $2 \mathrm{ml}$ ice cold $25 \mathrm{mM}$ Tris, 10 $\mathrm{mM} \mathrm{CaCl}_{2}, \mathrm{pH}$ 7.6. Bound and free hormone were subsequently separated by centrifugation at 3000 $\times g$ at $4 \mathrm{C}$ for $30 \mathrm{~min}$.

\section{Statistics}

All statistical comparisons were done by one- 
way analysis of variance (ANOVA). The significance of differences between groups were then assessed by Student's $t$-test using the Bonferroni calculation for multiple comparisons.

\section{Results}

For the validation of the RT-PCR methodology described herein, the kinetics of the PCR system and the detection and quantification of the RTPCR amplificates by HPLC was initially examined. The HPLC chromatogram of the pBR 322 Hae III digest shows a clear separation of the DNA fragments that are present in equal molar ratios (Fig. 1a). The larger DNA fragments had lower retention times than the shorter ones. A linear relationship could be established between the amount and size of the fragments applied and the corresponding HPLC peak integrals $\left(R^{2}=0.9\right.$, slope $=-22$, intercept $=0.0022, n=13$ ). Based on this correlation, the DNA fragment size or synonymously the amount of DNA was depicted as function of the extinction integral. Thus the HPLC-UV system was first applied to validate the PCR conditions. A representative HPLC-UV chromatogram of the amplified GHRH fragment is shown in Fig. 1b. Comparing the peak integrals from PCR aliquots, that were removed from the reaction tube after different numbers of cycles, the kinetics of the reaction could be recorded and by this the adequate number of cycles for further quantitative analyses, i.e. a number where the plateau phase of the PCR reaction is not yet reached, was established. The application of various amounts of RNA $(80,100$, $200,400,600,800$ and $1000 \mathrm{ng}$ ) resulted in linearily correlated peak integrals $\left(R^{2}=0.85\right.$, slope 940 , intercept 576052, $n=7, p=0.0091$ ) in the RT-PCR system.

To examine the variation of the RT-PCR system with subsequent quantification by HPLC-UV, the same RNA preparation was subjected 10 times to identical RT-PCR conditions. The PCR products were then quantified by HPLC-UV. The calculated coefficient of variation of the peak integral was $25 \%$. Considering the variation of the HPLCUV detection alone, which is less than $5 \%$ as determined by repeated analysis of the same PCR product, the PCR reaction with the various pipetting steps constitutes the major source of variation.

Using the RT-PCR method, GHR expression was demonstrated in several tissues. The specificity of the GHR RT-PCR amplificates was confirmed by restriction analysis. In most of the tissues investigated, RT-PCR amplificates of GHR-mRNA were detectable. Figure $2 a$ and $2 b$ show the electrophoretically separated amplificates. Their size was in accordance with the expected length of $438 \mathrm{bp}$. The quantities of the amplificates differed depending on the tissue investigated. Within metabolically relevant tissues (Fig. 2a), the strongest signal was obtained in cow's liver. In heifer's liver as well as in fetal's liver slightly fainter signals were observed, their intensity was comparable to that seen in mammary gland. GHR amplificates were also well detectable in kidney and in adipose tissue; clear but fainter signals were observed in ru-

a)

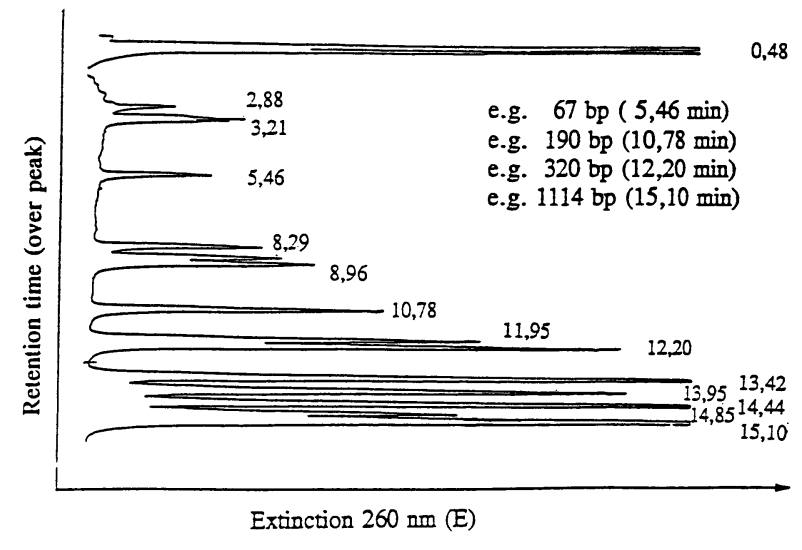

b)

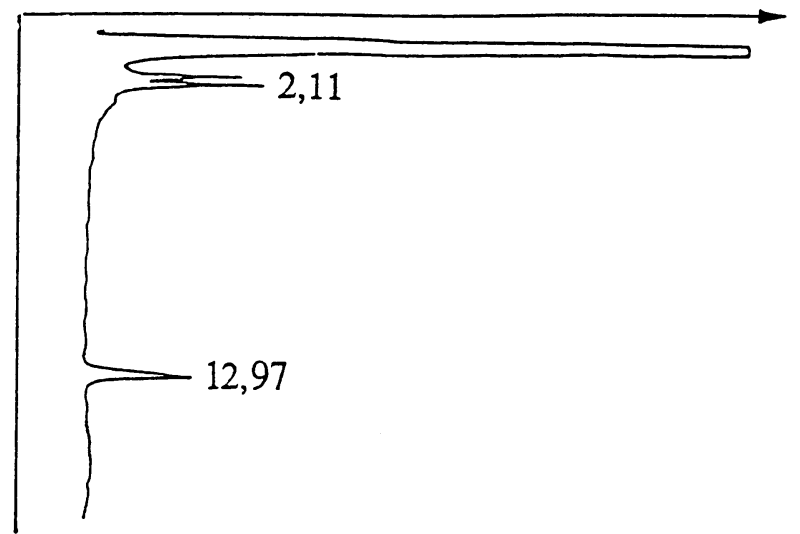

Fig. 1. a: HPLC chromatogram of the DNA standard (pBR 322 Hae III). b: HPLC chromatogram of the GHR amplificate. 
men villi and in skeletal muscle. Comparing the GHR amplificates in different reproductive tissues (Fig. 2b), in females the strongest signal was evident in uterine tissue, whereas in oviduct and in corpus luteum the amplificates were less intense. In ovary tissue, i.e. in the parenchyma without luteal or follicular compartments, no signal could be detected. In the male gonads, the GHR amplificates were hardly visible. In contrast, the strongest signal of all reproductive tissues investigated was evident in one of the accessory glands, the vesicular gland.

a)

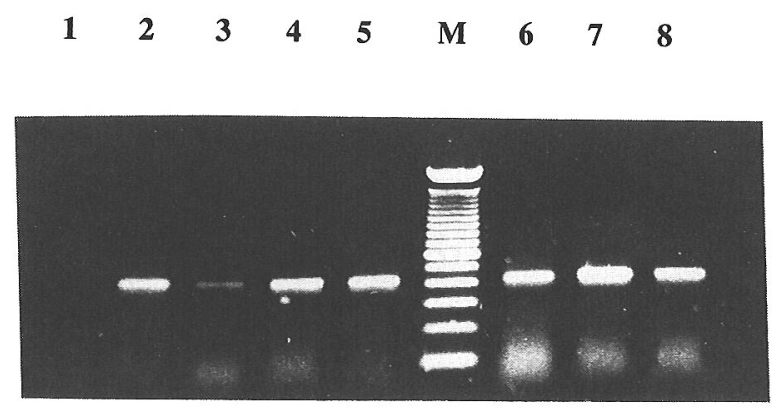

b)

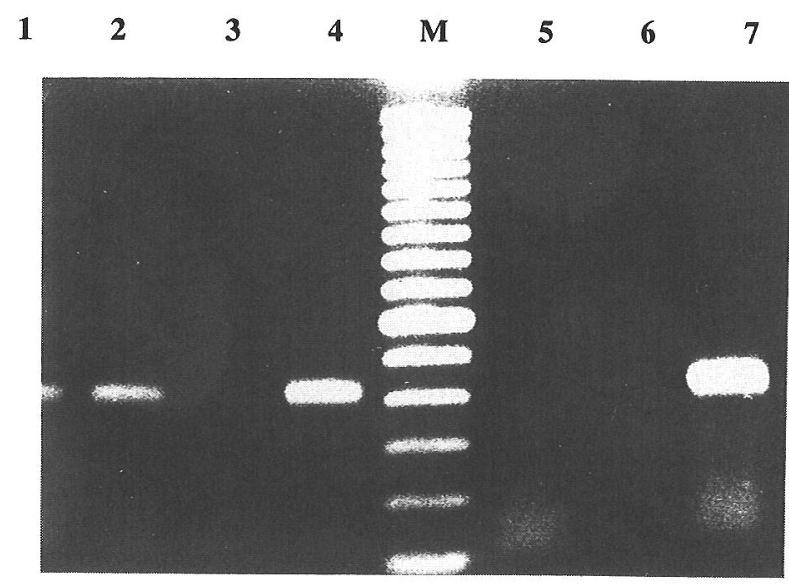

Fig. 2. a: Analysis of the bovine GHR mRNA in metabolically relevant tissues. M: $100 \mathrm{bp}$ DNAladder; total RNA of 1: muscle (heifer), 2: white adipose tissue (calf), 3: rumen villi (heifer), 4 : kidney (heifer), 5: liver (heifer), 6: liver (fetal), 7: liver (cow), 8: mammary gland (cow); $20 \mu \mathrm{l}$ from $100 \mu \mathrm{l}$ total RTPCR reaction, $1 \%$ agarose gel. b: Analysis of the bovine GHR mRNA in reproductive tissues. M: 100 bp DNA-ladder; total RNA of 1: oviduct (day 5/6), 2: luteal tissue (day 7), 3: ovary tissue (without luteal tissue), 4: uterus, 5+6: testes (bull 1 and 2), 7: vesicular gland (bull 1); $20 \mu \mathrm{l}$ from $100 \mu \mathrm{l}$ total RTPCR reaction, $1 \%$ agarose gel.
Besides the demonstration of GHR mRNA expression in various bovine tissues, potential regulatory effects of a long-term exposure to $\mathrm{bGH}$ on liver GHR were investigated at the mRNA level and at the receptor protein level. Table 1 shows the results for GHR mRNA expression (RT-PCR HPLC-UV) and for GH binding on liver membrane preparations from heifers treated with bGH. No significant differences for both parameters measured were observed between the treatment groups.

\section{Discussion}

The present study documents that RT-PCR is an appropriate method for the investigation of GHR mRNA expression in various bovine tissues. In combination with HPLC-UV detection the amplificates can easily be quantitated. Since any variations in pipetting and potential inadvertent changes in the conditions of the PCR reaction compromise the quantitative power of the method described herein to a much higher degree than the subsequent HPLC-UV analysis, the limitations of the present system are obvious. To circumvent these contingencies, the use of an internal standard, that can be coamplified with tissue RNA has been suggested [11, 12] to control the variability inherent in RT-PCR reactions. By that means a reliable and authentic quantification of mRNAs can be achieved. Nonetheless the validation of the method presented herein is at least applicable for semiquantitative comparisons, e.g. for comparing the abundancies of certain mRNAs in one given tissue.

Although the GHR and the prolactin receptor (PRL-R) display similarities in their cDNA sequence, amplification of PRL-R mRNA can be

Table 1. Effect of a long-term treatment with $b G H$ on liver GHR mRNA and on GH binding

\begin{tabular}{lcc}
\hline treatment & $\begin{array}{c}\text { GHR mRNA } \\
\text { (arbitrary units*) }\end{array}$ & $\begin{array}{c}\text { specific binding } \\
\text { (\% mg protein) }\end{array}$ \\
\hline controls & $183873 \pm 41772$ & $33.1 \pm 4.3$ \\
$320 \mathrm{mg} \mathrm{bGH}$ & $423836 \pm 43203$ & $49.4 \pm 3.9$ \\
$640 \mathrm{mg} \mathrm{bGH}$ & $302082 \pm 66436$ & $48.7 \pm 11.3$ \\
\hline
\end{tabular}

all values are given as means $\pm S E M ; n=4$ per group.

${ }^{*}$ RT-PCR amplificates were HPLC-UV analyzed, the peak intergrals are given. 
ruled out by the system used because of the lack of complementarity of the primers within the PRL-R sequence [13]. The mRNA origin of the amplificates obtained is evident from their size; amplification of genomic DNA, a potential contaminant of RNA preparations, would have resulted in larger amplificates due to the intron structure.

The transmembrane part of the GHR sequence was selected to provide the detection of the mRNA transcript of the full-length GHR mRNA and not of a potential mRNA transcript for a truncated GHR-form, the GH binding protein, that consists of the extracellular part only. Such a second GHR mRNA species has been described as a product of an alternate splicing event in pregnant mouse and in rat liver [14, 15]. For bovines, only one RNA species has been reported up to know $[4,16]$.

$\mathrm{GH}$ action is regulated at basically two different levels: at the secretory level and at the tissue level by GHR responsiveness. GHR gene expression in different tissues indicates a potential GH sensitivity, though there is a number of tissues were GHR mRNA has been demonstrated but the mature protein could not be demonstrated yet, e.g. the bovine mammary gland [16, present study] or the pituitary gland [17]. These discrepancies might be attributable to a true translatory failure or simply to methodological problems involved in GHR detection, possibly related to the relative high lipid portion in the respective tissues. However, the demonstration of GHR mRNA implies at least a potential sensitivity for $\mathrm{GH}$ action in the respective tissues. The strong GHR signal we observed in bovine liver is in accordance with the current concept of the liver being one of the main target tissues of anabolic, IGF-1 mediated GH action. Of particular interest in this respect is the evidence for GHR mRNA in bovine fetal liver, that is further questioning the notion of fetal growth being independent of GH. Increasing evidence has been presented recently that GHR is present in hepatic tissue during fetal life. In the fetal sheep GHR mRNA and specific oGH binding are present in liver as early as 51 days of gestation [18]. However, the absolute levels of GHR expression were much lower when compared to postnatal concentrations [18], whereas the signals we obtained for GHR mRNA amplificates from fetal, adolescent and adult bovine liver did not show this marked difference between pre- and postnatal life. Compared to liver tissue the amount of GHR amplificates we found in skeletal muscle was markedly lower. The presence of GHR mRNA in bovine skeletal muscle supports a local GH action in this tissue, though it is probably less sensitive than liver. GHR mRNA has been documented in skeletal muscle of another ruminant species, the sheep [18] and GH binding has been observed in pig muscle [19]. However, the mode of action, i.e. whether GH action is truly direct or whether it is locally mediated by somatomedins, remains open. The known physiological effects of $\mathrm{GH}$ on adipose tissue [20] are in good agreement with the strong GHR gene expression that we observed in adipose tissue. In our experiments GHR expression in the mammary gland was fairly exactly as intense as in liver. By these results the potential GH sensitivity of the bovine mammary gland, that has been demonstrated by Glimm et al. [16], is further supported. Using the Northern Blot technique with a rabbit cDNA probe, these authors observed a much weaker GHR expression in mammary gland than in liver. Hauser et al. [4] quantified densitometrically the hybridisation product detected in liver and in mammary gland from heifers in the fifth month of gestation and found a 30 times higher expression in liver than in mammary gland. This marked difference between liver and mammary gland GHR expression was not confirmed in the present study neither by gel electrophoresis nor by HPLC-UV of the PCR amplificates (data not shown). GHR has been detected immunohistochemically in the gastrointestinal tract of the rat [21]. In livestock species, the present documentation of GHR amplificates in rumen villi indicates that a potential site of $\mathrm{GH}$ action in ruminants might be via affecting villi metabolism and/or growth and thus via changes in nutrient resorption and availability.

In several reproductive tissues considerable variations in the degree of GHR expression were observed. Based on these results, local GH effects seem unlikely in testis whereas the vesicular gland appears as a potential GH target tissue. In contrast to our observation in bovine testes, Lobie et al. [22] localized immunohistochemically Leydig and Sertoli cells as major sites of GHR expression in the rat. The demonstration of GHR expression in bovine uterus supports the concept of uterine tissue being a potential GH sensitive organ. In female rats, the uterus has been shown to contain intense GHR immunoreactivity [22]. The GHR gene expression we observed in luteal tissue is in 
accordance with the recent immunohistochemical demonstration of GHR in bovine luteal tissue [23]. Given the translation and integration of the mature protein into the cell membrane, $\mathrm{GH}$ might thus be a potential regulator within some aspects of reproduction, e.g. for luteal function or for uterine development.

The observation that a long term treatment with bGH is not affecting liver GHR neither at GHR mRNA level nor at the protein level is in contrast to earlier studies where an upregulating effect of chronic exposure to exogenous GH on hepatic GHR has been documented. In sheep, GH binding to hepatic membranes was found to be increased after daily injection with bGH for 8 weeks [5]. In pigs, a similar increase has been described after a daily injections with porcine growth hormone over a period of 12 days [24]. Besides the different species (ovine and porcine versus bovine) and the differences in sex (male castrated lambs and young male pigs versus heifers) in the quoted and the present study, the length and the mode of application appear to be the most important differences. A treatment period of 38 weeks as in the present study has not been investigated yet with respect to hepatic GHR presently. Besides this long time, the slow release formulation might also cause differ- ences in the known responses to $\mathrm{GH}$ treatment. Though the reasons for the divergence between the different studies mentioned with respect to GHRH remain unclear, it should be pointed out that even under several months long GH exposure no tachyphylaxis to GH treatment is to be expected.

Our results demonstrate that RT-PCR can be successfully used to study GHR expression in various bovine tissues and that new potential targets for $\mathrm{GH}$ action can be thus identified. The quantification of the RT-PCR amplificates by HPLC-UV can be used to study the regulation of GHR under various conditions. Consistent with the results from GH binding studies, our data on GHR mRNA expression in bovine liver show that long-term treatment with a slow-release formulation of bGH has no significant effect on hepatic $\mathrm{GH}$ responsiveness.

\section{Acknowledgments}

The authors like to thank Prof. D. Schams and Prof. F. J. Schwarz, TU Munich-Weihenstephan, for the possibility collecting the liver samples from an experiment conducted under their supervision, and W. Mann for his help with the primer selection.

\section{References}

1. Gluckman PD, Breier BH, Davis SR. Physiology of the somatotropic axis with particular reference to the ruminant. Journal of Dairy Science 1987; 70: 442-466.

2. Karg H. Hormonale Manipulation des Wachstums. Übersichten Tierernährung 1987; 15: 1-28.

3. D'Ercole AJ, Stiles AD, Underwood LE. Tissue concentrations of somatomedin C: further sites of synthesis and paracrine or autocrine evidence for multiple mechanisms of action. Proceedings of the National Academy of Sciences USA 1984 1984; 81: 935-941.

4. Hauser SD, McGrath MF, Collier RJ, Krivi GG. Cloning and in vivo expression of bovine growth hormone receptor mRNA. Molecular and Cellular Endocrinology 1990; 72: 187-200.

5. Sauerwein H, Breier BH, Bass JJ, Gluckman PD. Chronic treatment with bovine growth hormone upregulates high-affinity hepatic somatotropic receptors in sheep. Acta Endocrinologica 1991; 124: 17.

6. Schwarz FJ, Kirchgessner M, Röpke R, Schams D, Kögel J, Matzke P. Effects of somatotropin treatment on growth performance and endocrine system in finishing beef heifers. Journal of Animal Science 1993; 71: 2721-2731.

7. Chirgwin JM, Przybyla EA, MacDonald J, Rutter WJ. Isolation of biologically active ribonucleic acid from sources enriched in ribonuclease. Journal of Biochemistry 1979; 18: 5291-5299.

8. Tayanger K, Hoffman AR, Kramer TB. A micromethod for the isolation of total RNA from adipose tissue. Analytical Biochemistry 1990; 186: 6063.

9. Katz ED, Dong MW. Rapid analysis and purification of polymerase chain reaction products by high-performance liquid chromatography. BioTechniques 1990; 8: 546-555.

10. Thorell JI, Johansson BG. Enzymatic iodination of polypeptides with ${ }^{125}$ I to high specific activity. Biochemica et Biophysica Acta 1971; 251: 363-369.

11. Wang AM, Doyle MV, Mark DF. Quantitation of mRNA by the polymerase chain reaction. Proceedings of the National Academy of Sciences USA 1989; 86: 9717-9721.

12. Becker-Andre $\mathbf{M}, \mathbf{H a h l b r o c k} \mathbf{K}$. Absolute mRNA 
quantification using the polymerase chain reaction (PCR). A novel approach by PCR aided transcript titration assay (PATTY). Nucleic Acids Research 1989; 17: 9437-9446.

13. Boutin JM, Jolicoeur C, Okamura H, Gagnon J, Edery M, Shirota M, Banville D, Dusanter-Fourt I, Djiane J, Kelly PA. Cloning and expression of the rat prolactin receptor, a member of the growth hormone/prolactin receptor gene family. Cell 1988; 53: 69.

14. Smith WC, Linzer DIH, Talamantes F. Detection of two growth hormone receptor mRNAs and primary translation products in the mouse. Proceedings of the National Academy of Sciences USA 1988; 85: 9576-9579.

15. Baumbach WR, Horner DL, Logan JS. The growth hormone-binding protein in rat serum is an alternatively spliced form of the rat growth hormone receptor. Genes and Development 1989; 3: 1198-1205.

16. Glimm DR, Baracos VE, Kennelly JJ. Molecular evidence for the presence of growth hormone receptors in the bovine mammary gland. Journal of Endocrinology 1990; 126: R5-R8.

17. Fraser RA, Siminoski K, Harvey S. Growth hormone receptor gene: novel expression in pituitary tissue. Journal of Endocrinology 1991; 128: R9-R11.

18. Klempt $M$, Bingham B, Breier BH, Baumbach WR, Gluckman PD. Tissue distribution and ontogeny of growth hormone receptor messenger ribonucleic acid and ligand binding to hepatic tissue in the midgestation sheep fetus. Endocrinology 1993; 132: 1071-1077.

19. Louveau I, Etherton TD. Characterization of somatotropin binding sites in pig skeletal muscle. Journal of Animal Science 1992; 70: 1801-1805.

20. Grichting J, Levy LK, Goodman HM. Relationships between binding and biological effects of human growth hormone in rat adipocytes. Endocrinology 1983; 113: 1111-1120.

21. Lobie PE, Breipohl W, Waters MJ. Growth hormone receptor expression in the rat gastrointestinal tract. Endocrinology 1990; 126: 299-306.

22. Lobie PE, Breipohl W, Aragon JG, Waters MJ. Cellular localization of the growth hormone receptor/binding protein in the male and female reproductive systems. Endocrinology 1990; 126: 22142221.

23. Lucy MC, Collier RJ, Kitchell ML, Meyer DM, Melton MA, Hauser SD, Krivi GG. Immunohistochemical and nucleic acid analysis of somatotropin receptor populations in the bovine ovary. $B i$ ology of Reproduction 1993; 48: 1219-1227.

24. Ambler GR, Breier BH, Surus A, Blair HT, McCutcheon SN, Silbergeld A, Gluckman PD. The interrelationship between and the regulation of hepatic growth hormone receptors and circulating $\mathrm{GH}$ binding protein in the pig. Acta Endocrinologica 1992; 126: 155-161. 